\title{
Reformasi and underground
}

After May 1998, the bid to introduce reform was felt in every possible field. The spirit of Reformasi instigated a negotiating and redefining of all kinds of issues, and the term reformasi was rather ubiquitous. All types of groups and organizations were inspired to use the word in their names. Nor did it stop there. The popularity of the slogan cast a wider net and spread to advertisements in which everything was transformed into a product of reform: 'reformation apartments' were on sale; special reformation religious journeys to Mecca (umroh reformasi) were promoted, and special offers for office space were advertised as a 'Reformation Package' (Van Dijk 2001:208-9). Indonesian cinema was not immune to Reform and various changes inevitably occurred at that time.

In the first chapter I discussed mainstream New Order film mediation practices and discourses which disclosed the politics of representation and imagination of Indonesian communities. This chapter is its antithetical image in that it presents post-Soeharto alternative, underground, or, as Gotot Prakosa (2005:3) has called them in English, 'side-stream' channels of film mediation practices and discourses. This is not to deny that also under the New Order alternative film productions and underground or sidestream modes of distribution and exhibition did exist. In the 1980s, experimental short films shot with $8 \mathrm{~mm}$ video or $16 \mathrm{~mm}$ film cameras were produced under the banner of 'street act cinema' (sinema ngamen), and 'guerilla film' (film guerilla). Such films were taken from one district to another and screened on walls, or sometimes bed sheets, which explains one of the nicknames given the cinema movement: 'drying [laundry] cinema' (sinema jemuran). ${ }^{1}$ Because this type of film existed outside mainstream channels for film production, distribution, and exhibition, however, it barely ever received a mention in Indonesian media.

1 Prakosa 1997:116-8. For more on sinema ngamen and 'side-stream' film, see Prakosa 1997.

(C) Katinka van Heeren, 2012 | DOI 10.1163/9789004253476_004

This is an open access chapter distributed under the terms of the Creative Commons

Attribution-Noncommercial-NonDerivative 3.0 Unported (CC-BY-NC-ND 3.0) License. 
After the resignation of Soeharto, side-stream cinema cultures and practices had the chance to gain visibility. The rise of new, alternative film genres and channels of distribution and exhibition transformed discourses on representations and imaginations of Indonesian communities. Many discourses, which were connected to comparable concerns in Third Cinema theories, evolved around themes of domination and resistance in post-Soeharto film mediation practices and society. Third Cinema theories addressed discourses on political and economic domination, and the global distribution of power of neo-colonialist First Worlds over Third Worlds. The theories on Third Cinema will be further explained below. In this chapter, I refer to Third Cinema on two different levels. In the first two sections, I allude to Third Cinema because comparable concerns were part of the post-Soeharto mediascape. In the third section, I broaden the analysis of discourses and use of Third Cinema theories. Here I connect discourses on representations of dominance and resistance to other post-Soeharto alternative channels of film distribution and consumption: side-stream film festivals and pirated Video Compact Discs (VCDs).

\section{REFORMATION IN FILM PRODUCTION: KULDESAK AND FILM} INDEPENDEN

The voice of an old man singing a song recalls the time of the struggle for Indonesian Independence; it is a song of pride, hope, and great expectations for the future. ${ }^{2}$ His singing is accompanied by an image of the Indonesian flag, the symbol of the nation's pride and glory. Yet, the flag is not blowing bravely and proudly in the wind, but is flapping weakly around the flagpole - a symbol of the confusion and disappointment of so many in an unstable Indonesia three years after President Soeharto had resigned. This shot was the last scene of the short independent, or indie, film Kepada yang terhormat titik 2 (To the esteemed:). The film was produced by Dimas Jayasrana and Bastian, students at the Jenderal Soedirman University in the rural town of Purwokerto, Central Java. It had its premiere there on 18 January 2002. The film shows how the common people of Purwokerto perceived their municipality. It captured urban life, and deliberately added a gritty touch by showing an impression of the lives of street vendors, street children, and farmers. At the end of the film, an old peasant recounts that throughout his life those

2 Part of this section was published in Inside Indonesia (Van Heeren 2002). 
in power never spared a thought for the meagre livelihood of the farmers of Purwokerto.

The production and screening of this film represented new developments in Indonesian cinema which emerged at the beginning of Reformasi. Between 1999 and 2001, in the midst of the euphoric atmosphere of reform and the seemingly limitless freedom of expression, film-making became a very popular activity in Indonesia. The widespread availability of new audio-visual technologies such as digital video cameras and projectors, liberally dosed with the spirit of Reform that permeated the Indonesian film scene, instigated the start of a new film movement. This new movement incorporated an array of new activities in film mediation practices and discourses on the subject. One element was the introduction of the label of independence, which gave birth to the new genre of independent film. Indonesian film independen should not be confused with the Euro-American meaning of 'independent' film, which stands for a movement which opposes the mainstream, mainly Hollywood, studio system. In Indonesia this genre became a model and banner for many young people who set out to make their own films. The scope of film independen transcended the production of independent films; it fostered the formation of a new community of mafin (an abbreviation of mahluk film independen, independent-film creatures). These mafin established their own channels of film distribution and exhibition through independentfilm festivals. Looking beyond the temporal limitations of a festival, they created their own forums to exchange thoughts on the subject of film on the Internet and by arranging regular meetings.

The incentive to undertake activities in the field of film independen really commenced with the production of the film Kuldesak ('Cul-de-sac', or Dead-end street), an anthology of four short features about such problems of the middle-class youth of the city of Jakarta as drugs, homosexuality, and the feeling of absolute desolation. Kuldesak was made by four young film-makers who decided to produce it 'underground' in 1996, breaking all the rules of film production of the New Order. The directors, Mira Lesmana, Riri Riza, Rizal Mantovani, and Nan Achnas, had a background in producing films, series, documentary-soaps, or music video-clips for television. Inspired by the cheap independent film production $\mathrm{El}$ Mariachi (1992) by Robert Rodriguez and his book on the film's production process, Rebel without a crew (1996), they decided to take the plunge and jointly produce a film for the silver screen.

Between 1996 and 1998, the four directors produced Kuldesak behind closed doors. To save energy, time, and money, they abandoned the beaten track of New Order film production. To start 
with, they did not register the production plan of Kuldesak at the Guidance Council of Film and Video of the Department of Information. In addition, as the film's directors, they neither obtained the mandatory membership of the KFT, nor did they follow the conventional New Order system in which it was only possible to become a film director after having been an assistant film director five times. As Kuldesak's producers, the four did not join PPFI. Finally, they did not force their amateur actors and actresses to register as members of Parfi. Eschewing all the formal channels, the directors and production team paid for the production costs of Kuldesak themselves, and were helped by actors and crew who joined the project for free. To distribute the film, they applied for foreign film funding.

Unexpected changes in the political situation enabled Kuldesak to reach the screens of the cinemas throughout Indonesia in November 1998. Many rules and restrictions for film production and exhibition of the New Order were dissolved by the process of Reformasi, which was at its peak at that time, and were applied less strictly. Apart from a mandatory last-minute registration with KFT, the team was excused for not having registered at the other official film organizations. Another hurdle was cleared when Kuldesak passed the censor. However, despite the freer political climate, one of the most radical scenes of this film - that of two boys kissing in a bus - was censored. Apparently this scene was too revolutionary even for Reformasi. Kuldesak reached the theatres of Cinema 21, and was highly successful among young audiences. In different cities, queues at the ticket office stretched outside the cinema buildings. Touching on controversial issues and filmed in an MTV-style, the film showed a departure from both films produced by the earlier generation of Indonesian film-makers and from the everyday sinetron (soaps) on television. The press labelled Kuldesak the first-ever Indonesian 'independent' film, and often highlighted its 'non- Indonesian' features.

Kuldesak, made by four film-makers who 'just went for it', triggered a euphoric energy among other aspiring young Indonesians. In 1999, the Komunitas Film Independen (Konfiden, Community of Independent Film) began to hold a series of 'travelling' film screenings (film keliling) and discussions in the bigger cities in Java. These were organized at cultural venues, educational institutions, and foreign cultural centres. The objective of the travelling screenings and discussions was to introduce the concept of independent film to a wider public. They were also a warm-up for the first Festival Film dan Video Independen Indonesia (FFVII, Indonesian Independent Film and Video Festival) held in Jakarta at the end of 
October 1999. This festival was designed to provide independent film-makers with a forum in which to screen their films. More ambitiously, it fostered a hope of reviving Indonesian film as a whole, an industry which had virtually died in the last decade of New Order rule. Besides organizing the annual FFVII between 1999 and 2002, Konfiden also published a monthly bulletin and commenced organizing workshops for film-making.

With the Jakarta-based Konfiden about to organize its third independent film and video festival in 2001, other parties in other cities (mainly in Java, but also in Sumatra, Sulawesi, and Bali) formed their own Indie film communities. These communities assumed the task of organizing independent-film festivals with discussions, workshops, and their own bulletins. Generally speaking, the independent films screened were rather unsophisticated and unprofessional. The majority consisted of short films made by young people in their early twenties who had no real background in film-making. This did not prevent them from broaching subjects which were often thought-provoking. Many included maverick ideas and depicted issues in the daily lives of the young, their interests, and sense of humour. Sometimes the films (indirectly) revealed issues of cultural, social, and political criticism. Some examples of films which circulated at the Konfiden festival and other film festivals of the time are: Revolusi harapan (Revolution of hope, 1997), by Nanang Istiabudi - a surrealistic story about a gang of thugs who go out on orders to kill and pull the teeth of artists, students, and others who are in any way critical; Dunia kami, duniaku, dunia mereka (Our world, my world, their world, 1999), by Adi Nugroho, which narrates the life of a transvestite in Yogyakarta; and Kameng gampoeng nyang keunong geulawa (The village goat takes the beating, 1999), by Aryo Danusiri, a chilling testament to the survivors of torture inflicted by the Komando Pasukan Khusus (Kopassus, Special Forces), filmed in Tiro, northern Aceh. These films were also screened at international film festivals and on other occasions.

As members of the various communities started to communicate on the Internet and visit each other's festivals, it did not take them long to begin to think about a coalition. About a hundred people from all over Indonesia, mainly film buffs and students from art academies and Muhammadiyah universities, came together in Yogyakarta for the National Indie Film Festival (Festival Film Indie Nasional) in late May and early June 2001. At the end, after much deliberation, they decided to form a national affiliation of independent-film communities. The next step was to establish an Information Centre (ICE), which operated an Internet mail- 
ing list called Forum Film, co-ordinated from Yogyakarta. The film communities also planned to hold a national meeting every two months. On 26 August 2001, during the Indie Film-Maker Meeting in Batu (a resort near Malang in East Java), the various communities tried to formulate a collective vision. They wanted to set up a programme to acquaint a broader public with the medium of film in general, and film independen in particular. After an all-night debate, three new ICE divisions were set up. Supplementing the earlier Forum Film mailing list, a web-site was to be co-ordinated from Malang, and an archive and a publication division were to be set up in Jakarta. The four ICE divisions would each remain autonomous bodies, standing for the same ideal but free to formulate their own policies.

The allotment of different divisions to different cities and their autonomy was a crucial issue during the debates. One reason the independent-film movement took on the form of a national alliance, in which the different communities remained 'independent' and retained an equal say, was the fear of domination by Jakarta. This was a legacy of New Order rule, when the Jakarta-based government officials and politics controlled the regions. Presumably not entirely coincidentally, at the same time that film communities were talking about independent divisions within a national alliance, on the political stage parties were engaged in fierce debates on a Bill that would give regional autonomy to the different provinces of Indonesia. Another spin-off of this reinforced commitment to regional autonomy in post-Soeharto film was that many new independent films made concerted efforts to reflect the characteristics of their home region. The film-makers wanted to produce a movie which differed in every sense from a film that would have been produced in Jakarta - something imbued with local pride and joy. For example, Topeng kekasih (English title: Dearest mask, 2000), by Hanung Bramantyo, is entirely in Javanese and revolves around the Oedipus complex, while Di antara masa lalu dan masa sekarang (Between the past and the present, 2001), by Eddie Cahyono shows the reflections of an old man about the guerrilla struggle for Independence. Both films depicted a typically Yogyakartan atmosphere. Another example of a film that explicitly reflected local culture is Peronika (Veronica, 2004), directed by Bowo Leksono from Purbalingga. This film is about villagers being baffled with technologies which are mainly used in the city. All dialogues are in Banyumas dialect.

The movie Kepada yang terhormat titik 2 alluded to earlier was another creative manifestation of this emphasis on locality. Both the film's contents and its production and screening in Purwokerto 
epitomized the re-invigorated expression of local identities in Indonesian film and on the political stage. By 2003 the euphoria of Reformation had passed its peak, and so had the film indie movement. Several ICE divisions had stopped operating because of a chronic lack of funding, the dim prospects for turning the coalition into an official organization, and internal private conflicts. These conflicts revolved around questions of leadership, disputes over what direction to take, clashing personalities, and, at times, envy and distrust. By 2003 it was increasingly unclear exactly what Indonesian independent film was supposed to stand for. For some, independent film meant just any film produced outside the New Order system of film production. To a few, it also meant that films had to be produced for less commercial motives. In their opinion commercial film was contaminated by the New Order politics of economic growth, and a derivative of its structures of crony capitalism. ${ }^{3}$ They believed that because the New Order had treated film as a commercial commodity, it had crippled the production of domestic films with the exception of cheap commercial films filled with sex, violence, or slapstick humour. In their eyes, the combination of film and commerce implied structures of New Order domination. Others believed that independent films tackled daring subjects, broached innovative subjects, and depicted the film-maker's free artistic expression. Yet others thought that independent film meant the production of low-budget, technically inferior, (short) films, filmed by unskilled film-makers with a digital camera. Some people even thought the term stood for the production of films about the Indonesian struggle for Independence in 1945.

Another reason why the use of the term film independen had lost its appeal, was that within the broader context of Indonesian film the label was connected to too many different groups. Broadly speaking, these groups could be divided into two factions. In mainstream media, the four directors of Kuldesak and nine other directors who produced music videos, soaps, and documentaries for television, were said to represent independent film. In October 1999 these directors had formed a movement based on a manifesto called 'I-Sinema'. I-Sinema was inspired by a movement of avant-garde Danish film-makers who in 1995 had drafted a manifesto called Dogme 95. The 'I' in 'I-Sinema' had different meanings - it stood for the words 'Indonesian', 'Independent', and also other terms like the English 'eye' or even 'I' (Sharpe 2002). The I-Sinema film-makers were not overly concerned about whether they were called independent film-makers or not. The main point

3 See, for example, Prakosa 2001:3-4, and Chapter 1 of this book. 
of I-Sinema was to find new ways to produce films for the silver screen in order to revive the Indonesian film industry. In the manifesto, the use of digital technology was mentioned specifically as a new tool allowing the film-makers the opportunity to work more freely and independently (Sharpe 2002). On the other hand, the label of 'independence' was used by members of the above mentioned different film indie communities across Indonesia. These communities consisted of amateur film-makers, the majority of them students, who tried to produce films on a shoestring budget, borrowing money and film equipment from friends and family. In these communities, there was plenty of discussion about what independent film really meant. In their opinion, in comparison to themselves, the I-Sinema film-makers were well-established film directors who had easy access to film equipment, funding, and even the theatres of Cinema 21. Some members of the indie groups were of the opinion that if the I-Sinema film-makers were seen as independent film-makers, everyone producing a film in Indonesia could be labelled independent, particularly since there was no real film industry to speak of anyway. ${ }^{4}$

When in 2002 and 2003 the private television station SCTV began organizing an independent-film-festival competition, members of these more 'hardcore' indie film communities decided to drop the term. They were convinced that the label of independent film had now been hijacked by the commercial television industry, and therefore was not worth holding onto. Despite the wrangling, SCTV's Festival Film Independen Indonesia (FFII, Indonesian Independent-Film Festival) was a big success. In the first year, 1,071 short films were submitted to the festival committee, of which 836 qualified to enter the competition. In the following year this number rose to 899 films (Prakosa 2005:81). The films were from all over Indonesia - places as far afield as Berau (a city on East Kalimantan), Banyuwangi (the outermost point of East Java), Mataram (a town on the island of Lombok), the island of Batam (off the coast of Sumatra), the Sumatran cities Medan and Padang Panjang, as well as such smaller Javanese towns as Wonogiri and Cilacap. They were made by a variety of people ranging in age from nine to seventy. Among those who registered their films at the SCTV festivals were primary school students, bureaucrats, housewives, journalists, and police officers (Prakosa 2005:7-9). In particular after the SCTV festivals, the label 'independent film' often tended to fall by the wayside. As the term was burdened with too many dif-

4 Personal communication with members of Konfiden, Kine Klub UMY, Bulldozer, and other independent film communities in Jakarta, Yogyakarta, Malang, and Surabaya in 2001 and 2002. 
ferent definitions, and represented too many different groups of film-makers, the indie communities decided to forget about debates to find a single definition for film independen. They decided that no matter what format, formula, subject, or label was used to describe their movement, it was best just to focus on the goal of bringing domestic film back to the people of Indonesia.

DISTRIBUTION AND EXHIBITION OF NEW MEDIA FORMATS: 'LOCAL'

BETH VERSUS 'TRANSNATIONAL' JELANGKUNG

When the production and screening of film independen was at its height in 2001, discussions on film distribution and exhibition began to cover the problems of access of domestic films to the topend cinemas of Cinema 21. These discussions were fuelled by the case of Beth (Aria Kusumadewa, 2001), a domestic film scheduled for screening in one of the theatres of Cinema 21 at the end of November 2001. This screening did not materialize, however, as negotiations between the film's director and bookers of Cinema 21 failed and the film was withdrawn from mainstream channels of film exhibition. Instead, it was distributed and screened through alternative networks set up by film independen communities. The failure of Beth to reach Cinema 21 theatres prompted discussions about existing power structures in Indonesia in relation to film and local and national/transnational identities. Particularly in the discussions about Beth held at film indie meetings and on mailing lists on the Internet, the Cinema 21 network was made to epitomize entrenched New Order structures. Allegedly, the network gave access only to those Indonesian film-makers or films representing upper-middle-class transnational identities, meaning well-to-do people who can afford schooling at universities in Indonesia or abroad.

Only a few months after the resignation of President Soeharto, Indonesian film productions began to reach the screens of Cinema 21. Most films were made by film-makers who had received their film education at the Faculty of Film and Television at the Institut Kesenian Jakarta (IKJ, Jakarta Art Institute), but now others who had mastered the technical aspects of film-making abroad also began to produce films for domestic audiences. In 2001 two digital films, made by semi-professional film-makers who had received film education in the United States, were screened in Cinema 21 in Pondok Indah, South Jakarta. Including these two productions, around ten domestic films were screened in Cinema 21 between 
1998 and 2001. The growing number of domestic films, both in $35 \mathrm{~mm}$ and in digital video format, reaching Indonesian top-end cinemas prompted discussions in national media on 'the birth of a new generation of Indonesian film-makers' and 'the revival of Indonesian cinema'. Even though most films were art movies which were not enormously popular with a broad audience, the mere fact that they were produced and reached Indonesian cinemas seemed to offer a source of hope for the future of Indonesian film.

In October 2001, the film Jelangkung (Rizal Mantovani, 2001) was released, which was a huge success in theatres belonging to the 21 Group. ${ }^{5}$ With the unexpected success of Jelangkung the future for Indonesian film in domestic cinemas seemed brighter than ever. Jelangkung was directed by music-video director Rizal Mantovani, and produced by soap actor and producer Jose Poernomo, who had recently founded his own production company, Rexinema. The film was made purely with commercial objectives. The producers stated they wanted to make a film that would simply entertain, and not in any way deal with any moral or social messages, or other, often incomprehensible, 'heavy stuff' (Agustin 2002; Sitorus 2001). Jelangkung was produced in two weeks and shot on digital video format. The film is about a group of teenagers who set out to trace ghosts based on legends of haunted places in Jakarta. The director and producer of Jelangkung were inspired by two popular American horror films, The Blair Witch project (Daniel Myrick and Eduardo Sànchez, 1999) and Fright night (Tom Holland, 1985). They used a combination of elements from these two films and translated this into an Indonesian setting using urban legends of Jakarta.

Jelangkung was initially screened in only one of the movie theatres of Cinema 21 in Jakarta. This theatre in Pondok Indah Mall was the only theatre in which a video-projector could be operated for the preview of films or presentations. However, as were other Cinema 21 theatres, it was equipped only with standard $35 \mathrm{~mm}$ projectors. For that reason, the producers themselves had to supply the video projector to screen the film. Because of word-of-mouth promotion, which praised the film's story and its musical score, as well as the gossip that a real ghost had slipped into the film during recording, Jelangkung became a real hit, initially among teenagers whose enthusiasm passed on to other categories of audiences. People were queuing for hours at the Pondok Indah box office to obtain tickets which were sold out in only a few minutes. Because the film was such a success, in December 2001 the producers

5 A jelangkung is a doll made out of a coconut shell and some wooden sticks, which is used as a medium to invite spirits to possess it. 
decided to make copies of Jelangkung in Singapore, 'blowing it up' to the $35 \mathrm{~mm}$ format. This way the film could be screened in different cinemas. To illustrate the huge popularity of the film: at that time the costs of transferring digital film to $35 \mathrm{~mm}$ were approximately Rp 400 million (US\$32,000), plus an extra amount of Rp 13 million (US\$1,040) per copy. By February 2002, twenty-four Cinema 21 theatres all over Indonesia screened Jelangkung (Agustin 2002). In January 2002 Jelangkung attracted even more viewers than the just released Harry Potter and the sorcerer's stone (Chris Colombus, 2001), which was a worldwide success. The enormous success of the film attracted the attention of some American film companies, such as Miramax and Vertigo Entertainment, which expressed an interest in previewing the film and perhaps turning it into an American version. ${ }^{6}$

With both the rise in production of domestic films and their unproblematic distribution to prestigious cinemas, it seemed that after the fall of Soeharto domestic film had met a more conducive environment. When Jelangkung became a box office hit, film producers and journalists started to believe that Indonesian cinema had been successfully 'reformed', but this optimistic idea was questioned by the case of Beth. Beth, a film directed by Aria Kusumadewa, was an independent production. The idea of producing the film was born out of nightly conversations of the director with artists, famous local actors, actresses, and other individuals from various backgrounds frequenting Bulungan in South Jakarta. This group, which called itself Komunitas Gardu (Security Post Community), wanted to make a film that criticized the contemporaneous Indonesian socio-political situation. The story of Beth is about a forbidden love between a boy and a general's daughter, who meet each other again in a mental institution. But, the director argued, the film is actually a comment on Indonesian society, in which there is a thin line between sane and insane behaviour. In Beth, the mental institution and its inhabitants form a representation of Indonesia in miniature, exposing characteristics of different members of Indonesian society. Here, no one really is what he or she seems to be. The mad really are sane, the sane really are mad, and almost everyone can be bribed. The director, crew, actors, and actresses financed the production of Beth themselves, but a lack of funding meant its completion took a few years. To save production costs Beth, as was Jelangkung, was shot on digital video.

It was planned to have the national premiere of Beth at the Jakarta International Film Festival (Jiffest) in October 2001. Jiff-

6 'Produser AS tertarik pada film "Jelangkung"', Pos Kota, 27 January. 
est was organized for the first time in November 1999, as a forum to screen both international and Indonesian films which were not likely to enter mainstream channels of distribution and exhibition. After Jiffest, Beth would be distributed to Cinema 21 in Jakarta, and thereafter to other cities in Indonesia via alternative networks. This was not to be, however, as the screening of Beth at Jiffest turned into a controversy. When the director discovered that the organizers of Jiffest paid a screening fee for some foreign films, he demanded the same treatment for his film. In a discussion between Aria and the organizing committee of Jiffest, it was explained that screening fees were only charged for some of the films entered in the festival. These were films that had been very successful abroad and were likely to attract large audiences at the festival. The committee assumed Beth could never compete with these films, and even considered its screening at the festival a complimentary promotion. Moreover, since Jiffest would require a digital video projector to screen it, the committee saw no need to pay extra for its screening. Frustrated, Aria felt that his film was not valued as much as foreign films, and he decided to cancel the screening of Beth at Jiffest. In the local mass media, he voiced the criticism that Jiffest favoured foreign films above domestic productions, and thereby showed contempt for Indonesian film.

Although there was no premiere of Beth at Jiffest, other options for screening the film were still open. A few days before Beth was withdrawn, a message had already been posted on the Internet stating that Aria was looking for partners outside Jakarta to screen his film. Soon after this posting, various film indie communities from different regions showed their interest in collaborating with Aria. Besides these alternative offers, Aria had settled with the management of Cinema 21 that his film was going to be screened in the Pondok Indah theatre at the end of November. But here the screening of Beth ran into another problem, leading to a second controversy. Riding the crest of its unexpected success, Jelangkung, which had only been expected to last ten days at the most, was still being screened in the Pondok Indah theatre in November. As the Pondok Indah theatre was the only cinema where films in digital video format could be operated, the screening of Beth was initially postponed to the first week of December, and thereafter indefinitely.

This was a huge problem for Aria. He had to rent a digital video projector (LCD), at that time around Rp 2.5 million (US $\$ 200$ ) for one day up to Rp 6 million (US\$ 480) for seven days, and pay for film posters and other promotion material for screening at Cinema 21. To cover these costs, Aria needed sponsoring, but to obtain funding from a potential sponsor, he needed to know the 
exact screening schedule. Several times he tried to obtain a fixed schedule from the management of Cinema 21 but did not succeed. Instead, he was told that the policy of Cinema 21 did not permit two Indonesian films to be screened at the same time. As long as Jelangkung was still popular, Beth would be put on hold. Due to the uncertainty of the film's screening schedule, it was impossible for Aria to negotiate with sponsors. At the end of December 2001, out of sheer frustration and disappointment, he withdrew the proposed screening of Beth from Cinema 21. Instead, Aria decided to focus fully on distributing and screening the film via alternative channels.

The discord between Aria Kusumadewa and Cinema 21 erupted into a controversy in the Indonesian mass media. In entertainment and celebrity infotainment television programmes Aria and two of the leading actresses of Beth, Lola Amaria and Ine Febriyanti, spoke their minds about what they perceived to be the unfair treatment of Indonesian film by the management of Cinema 21. They suggested that Cinema 21's policy of not screening two Indonesian films at the same time was related to business deals on film distribution and exhibition between the Subentra 21 Group and the American Motion Picture Association. Hollywood films were scheduled months in advance and entered many different cinemas simultaneously, whereas Indonesian films had to line up to be screened one at the time. The case of Beth led to heated debates about the position of domestic film in Indonesian cinemas and even drew the attention of the non-governmental organization Media Watch, resulting in an investigation into an alleged monopoly on film distribution and exhibition in Indonesia by the 21 Group. $^{7}$

Hindered by accusations of nepotism, the theatre management of Cinema 21 blamed the failure to screen Beth in its theatres on problems of adaptation to new media technologies. With the exception of one Pondok Indah theatre, all other cinemas could operate the $35 \mathrm{~mm}$ film format only. As such, the case of Beth could basically be perceived as a problem of adjustment of conventional technologies of film exhibition to new film media and formats. The problem of the adaptation of established cinemas to new audio-visual media technologies was not a problem of Cinema 21 alone. All over the world cinemas equipped with $35 \mathrm{~mm}$ projectors for film exhibition

7 In the light of these discussions, in July 2002 Media Watch came up with a report which noted nine violations of the Indonesian anti-monopoly law of 1999 by the 21 Group. Media Watch filed a complaint with the Komisi Pengawas Persaingan Usaha (KPPU, Business Competition Supervisory Agency) alleging unfair business practices by Subentra 21. The case was taken to court. In April 2003 the verdict handed down was that there was neither proof of monopoly, nor of unfair business practices by the 21 Group. 
had difficulties adapting to the new developments in film productions in digital video format. In most cases digital films were first transferred to $35 \mathrm{~mm}$ before they reached the screens of cinemas or film festivals. Nevertheless, discussions about Beth's failure to reach Cinema 21 tended to overlook this point. Instead the discourse focused on issues raised before, such as the link between trade and power, structures of nepotism, and the domination of the Indonesian film industry by the middle classes.

The failure to distribute Beth through mainstream distribution channels was a particularly hot topic in discussions about film on the Internet and at gatherings of film independen communities. Here, many discussions again emphasized that it was imperative to set up a diverse and competitive system of film distribution and exhibition, free of business interests and state control. The growing appeal for alternative networks which would show a diversity of films in opposition to the uniformity on offer in Cinema 21 fuelled discussions about the potential of local film productions. As mentioned earlier, the idea was that local films could articulate free artistic expressions and specific local identities. Learning from the distribution problem experienced with Beth, members of film indie communities developed this idea further into the concept of creating regional cinemas (sinema daerah). In regional cinemas, the production of local films would challenge what Yogyakarta film-maker Doni Kus called 'the colonization of [film] aesthetics' ('penjajahan estetis') by Jakarta and the rest of the world. Kus' point was that regional cinema had the potential to be individual, original, and resistant to both Hollywood mass products imported into Indonesia, and commercial films and television soaps produced in the Jakarta-based film industry. ${ }^{8}$ The hope was that the potential rise of regional cinema would produce a break with the policy of the 21 Group, which prioritized the screening of films in Jakarta before distributing these to the regions.

The issues raised in discussions on Beth correspond with themes found in Third Cinema discourses. The goal of Third Cinema was to raise questions about domination and resistance in 'non-Western' film cultures. The political disposition of economic domination, and concomitantly the global distribution of power of First over Third Worlds, was an important aspect of its theories. Ella Shohat

8 Kus' statement about 'the colonization of aesthetics' by the Jakarta-based Indonesian film industry was made at a film indie meeting in Yogyakarta in December 2001. At that meeting local film-makers were talking about founding a Yogyakarta-based film industry. This industry was to be supported by the local government and the Sultan of Yogyakarta, and would be called Mataram film. 
and Robert Stam identified forces of neo-colonial globalization and domination by a group of powerful nation-states consisting basically of Western Europe, the US, and Japan. This domination, they argued, was economic ('the Group of Seven', IMF, the World Bank, GATT), political (the five veto-holding members of the UN Security Council), military (new 'unipolar' NATO), and techno-informational-cultural (Hollywood, UPI, Reuters, France Presse, CNN). Neo-colonial domination, Shohat and Stam (1994:17) asserted, was "enforced through deteriorating terms of trade and the "austerity programs" by which the World Bank and IMF, often with the self-serving complicity of Third-World elites, imposed rules that First-World countries would themselves never tolerate'. Challenging such hypocrisy, they addressed the unequal terms of exchange and global distribution of cultural productions, pointing out that the economic dependency of Third World countries made their cinemas vulnerable to neo-colonial pressures. Hollywood films that had covered their costs in the domestic market could profitably be 'dumped' on Third World markets at very low prices. When dependent countries tried to strengthen their own film industries by setting up trade barriers for foreign films, First World countries could threaten retaliation in some other economic area, such as the export or pricing of raw materials (Shohat and Stam 1994:30).

As in the case of Third Cinema, the majority of discourses about film independen and post-Soeharto film mediation practices during and after the case of Beth addressed the position of nationally hegemonic dominant film practices and the modes of resistance open to minoritarian regional cinemas. Discussions about the position and treatment of non-commercial domestic film in the Indonesian mediascape (mainly in cinemas, but also at Jiffest and on national television), and the need for oppositional regional cinemas and alternative distribution and exhibition networks, revealed the efforts made to shed the legacies of New Order hegemonic rule in film and society. Several discourses implied that the post-Soeharto mediascape was a post-neo-colonial setting. In film, the New Order was marked as an imperialist force in its own right, a part of a process of neo-colonization of hegemonic Western culture through the connections and business deals of Soeharto cronies with transnational media corporations.

In Indonesian studies, the idea of the New Order as neo-colonizer is not new. Benedict Anderson has said that the struggle for independence and the years that followed represented the defeat of the colonial state by a newly imagined nation. Soeharto's New Order, on the other hand, 'is best understood as the resurrection of the State [founded in Dutch colonialism] and its triumph vis-à-vis 
society and nation' (Anderson 1990:109). Speaking of Third Cinema theories, Krishna Sen also treated the New Order as a neocolonial force that disseminated national culture in the same way as neo-imperialistic forces distributed global Western culture. Sen $(2003: 156,163)$ argues that under the New Order, local or global culture rather than hegemonic national culture could be perceived as modes of resistance.

Sen (2003:147) felt that "the globalist paradigm of Third Cinema theorizing [did] not quite capture the radical drives within Indonesian cinema'. Instead, she argued, Indonesian cinema's radicalism needed to be defined in terms of the political constellations within the nation and could not be read in any generalized way in relation to Hollywood, global culture, or capitalism (Sen 2003:147). There is more than a grain of truth in this, but in discourses on the case of Beth, Hollywood was equated with political constellations within the nation. Hollywood and concomitantly the domination of global culture were seen as examples of the structures of New Order rule that supported crony capitalism. A tangible example of this was the involvement of Soeharto cronies in import and export deals with the US. The most glaring case in point was that Soeharto's foster brother Sudwikatmono, owner of Subentra 21, had secured the exclusive distribution and exhibition rights of imported US films. Another such link became apparent when Soeharto's business partner Bob Hassan was involved in a deal between Indonesia and the US at the beginning of the 1990s. In exchange for Indonesia importing Hollywood films, the US agreed to import batik and timber from Indonesia. In this light, the representation of Beth and its connection to alternative film cultures and side-stream, independent, or underground networks of film distribution and exhibition can be seen as part of Third Cinema discourses, which set minority oppositional cinemas against their dominating counterparts. In the post-Soeharto mediascape, the mediation practices of film independen as a movement of oppositional cinema were perceived to be a counterpoise to the enduring structures of the New Order and its incorporation of Hollywood/First World domination in Indonesian cinema. In post-Soeharto cinema, 'Third' as a denominator of opposition stood for local Indonesian film cultures and identities, whereas 'First' represented hegemonic global and national culture.

The emphasis on the local as subversive or oppositional to national or global culture and identities in post-Soeharto cultural discourses can be linked to Arif Dirlik's views about the re-emergence of the local as a site of resistance and struggle for liberation. While Dirlik (1996:35) notes that such struggles are informed by the modernity that groups suppressed or marginalized by modern- 
ization reject, the local film indie communities felt that they were neither suppressed by modernization, nor were they rejecting it. Instead, in step with movements of Third Cinema, the communities highlighted localism as a point of departure and goal of liberation, which questioned and opposed the imbalanced access to national and transnational film distribution and exhibition networks.

\section{ALTERNATIVE SITES OF FILM CONSUMPTION: ADDITIONAL}

IDENTIFICATIONS AND MODES OF RESISTANCE

In the years following Reformasi, film festivals began to proliferate everywhere in Indonesia. Besides the movement of film independen with its various film screenings, discussions, workshops, and festivals, after 1999 other groups and communities also undertook the organization of film festivals. Some festivals with special themes saw the light of day only once, for example the 2002 Festival Film Perdamaian (Peace Film Festival), which screened domestic and international films about human rights issues. Other festivals were held annually. Most festivals emerged from communities which either drew on or 'claimed' particular film genres or formats. Sometimes new genres were formed or co-opted - 'peace' or 'gay and lesbian' films spring to mind - or concepts of existing genres changed. Documentary film, which was equated with propaganda under the New Order, was now transformed into a genre which epitomized the advocacy of human rights issues and the deconstruction of New Order narratives on history and society. The various new film festivals catered to different imagined audiences and were connected to a new set of discourses, related to concerns in society or daily life. ${ }^{9}$ Besides the specific choice for a film genre or format, another important feature of the new festivals was that nearly all of these combined the screening of domestic and foreign films.

The most important post-Soeharto festival on a national scale was Jiffest, Jakarta's international film festival. Jiffest was organized for the first time from 20 to 28 November 1999, a month after the first independent-film festival by Konfiden. Two women, the Indonesian producer and documentary film-maker Shanty Harmayn and the Franco-American festival organizer Natacha Devillers, founded the festival to provide audiences with foreign films

9 At SCTV's FFII in 2002 and 2003, Prakosa (2005:83) noticed that the main themes of films at various film festivals, including SCTV's, were: love, drugs, togel (abbreviation of toto gelap, illegal lottery), dreaming or daydreaming, and homosexuality. 
and art films, which were hard to find in Indonesia. In his review of the first Jiffest, cultural critic Seno Gumira Adjidarma spoke of the rise of a new generation of film-makers and film audiences. ${ }^{10}$ Over the years Jiffest grew into a big event that screened all kinds of classic, modern, short, and experimental films and documentaries, both from Indonesia and abroad. Alongside its annually changing theme, different workshops and discussions were also organized during the festival. After 2001, a section of Jiffest travelled throughout Indonesia to screen part of its film programme in cities across the country. In its fourth year, Jiffest expanded this section by having local film-makers in each city enter their own films and screen these alongside the regular programme.

Another new Jakarta-based film festival which was held annually and which also travelled to other cities was the Queer Film Festival (QFF). The QFF was organized for the first time by the 'Q-munity' in September 2002. Q-munity was a community which consisted of gays and lesbians and other people with an interest in film and arts. The QFF was the first Indonesian film festival to cover the genres of gay, lesbian, and Aids films. The festival was non-competitive and screened both international and domestic productions. Beyond its core screenings, at the fringes of the festival there were discussions with film-makers, photo and painting exhibitions, and seminars about such topics as Aids. QFF tried to keep a low profile because various groups in Indonesia do not accept homosexuality. To reduce the focus on homosexuality, the committee strategically tied its festival to campaigns about Aids awareness and the dangers of free sex. Despite such manoeuvres, Q's director John Badalu regularly received threats from Muslim fundamentalists who tried to stop the event each year.

Other recurring film festivals which were tied to either a certain format or a particular genre included the Pesta Sinema Indonesia (PSI, Feast of Indonesian Cinema), the Festival Film Dokumenter (FFD, Documentary Film Festival) and Hello;fest. From 2001 to 2005, PSI was held each June in Purwokerto. It was organized by a group of students who formed a community called Youth Power, which was also active in the field of theatre, arts, and photography. The festival exclusively covered the screening of films produced in video format. These films consisted of domestic as well as foreign films. In 2005 the PSI added a 'one minute film' competition for local Purwokerto film-makers to its programme. Since 2002, the komunitas film dokumenter (documentary film community) has organized FFD each year in December in Yogyakarta. This festi- 
val has screened both international and domestic documentaries, and organized a competition for documentaries produced by novice domestic film-makers. Besides the screening of documentary films, it has also organized workshops on documentary making and discussions. In 2005, FFD added a competition for professional Indonesian documentary film-makers to its programme. Hello;fest commenced in 2004, when it was organized by the film school Hello; Motion in Jakarta; it focused on short and animation films. Hello;fest began as a festival to screen the work of its students at the end of their four-month courses, but because many outsiders also wanted to participate in the festival it changed into an open forum. Besides the screening of films by students and outsiders, some domestic and foreign films are invited to compete for four awards each year, for which the viewers at the festival can vote (Ratna 2005).

Another alternative site of film distribution and consumption was connected to the VCD format. This format was preceded by video cassettes and laser discs (LD), and followed later by Digital Video/Versatile Discs (DVD). In Indonesia the distribution of these new film formats started in the mid-1980s under the New Order with the introduction of video players and cassettes onto the Indonesian film market. Instantly people, mainly from the middle classes, embraced the medium. In a short period of time, video began to compete with cinemas and layar tancep. Many retired highranking military officers, who had often occupied a position in local offices of the Department of Information, set up mobile video companies in provincial areas backed by the licenses they handed out themselves (Adityo 1996). At the beginning of the 1990s a new format, LD, was added to the distribution of video. In 1996 the LD format was increasingly replaced by VCD, which in 2000 was followed by the DVD format. However, in Indonesia DVDs did not immediately replace the circulation of the much cheaper VCDs.

With the introduction of video, film piracy was launched with a vengeance on the Indonesian market. Pirated films were very popular. Apart from their low price, about one-half to one-third of the price of original products, pirated films often circulated before the original film reached Indonesian cinemas. Unquestionably, part of their popularity was that pirated films were not censored. ${ }^{11} \mathrm{Com}-$ pared to films in cinemas and the original products sold in shopping malls, which mainly consisted of the same Hollywood and local

11 'Akan dicari sampai ke akarnya', Suara Pembaruan, 11-12-1997; 'LD/video beredar mendahului film impor terbaru di bioskop', Harian Ekonomi Neraca, 24-1-1996; 'VCD hasil bajakan dijual sangat murah; LSF berperan menegakkan UU Hak Cipta', Pikiran Rakyat, 10-9-1999. 
products, the variety obtainable in pirated films was much more diverse. Pirated films included classic and art house films, Mandarin, Hong Kong, and Bollywood film productions; many productions moreover consisted of pornographic or semi-pornographic films. The piracy of films in video, LD, and later VCD and DVD format launched an extensive underground economy (F.Y. 1993). In August 1997, Wihadi Wiyanto, Secretary General of the Asosiasi Importir Rekaman Video (Asirevi, Indonesian Video Recording Importers Association), stated that $90 \%$ of the VCDs circulating in Indonesia were illegal copies. ${ }^{12}$

VCD was perceived as a medium and format accessible to all people. Even though the quality of VCD was second rate compared to videotapes and LD, it was cheap. Because of their price and quality, videotapes and LD were perceived as formats used by the middle classes (Nurhan and Theodore 1999a). In contrast, especially because of film piracy, even the poorest people could watch a VCD. Indeed pirated VCDs were even cheaper than their originals, though often of inferior quality. With the exception of fairly professional reproductions of a master copy, many pirated films had indistinct, blurred images and sound. Some of these pirated films were digital video recordings of films screened in cinemas or on videotape or LD at home. This was betrayed by the fact that movie theatre audiences could be heard commenting on the film; other nuisances which had been inadvertently recorded included people walking by the screen, kitchen noises, the crowing of a cock, or children playing in the background. Because of their inferior quality it was said that pirated VCDs had their own market segment, consisting mainly of the lower classes. ${ }^{13}$ It was asserted that the number of pirated products circulating in rural areas was much higher than in cities, ${ }^{14}$ but in my experience virtually everyone, rich and poor, nearly everywhere in the city or in the countryside, consumed pirated VCDs.

Until 1997 pirated films were imported mainly through transnational underground networks operating in Singapore, Malaysia, and Hong Kong. Until 1998 most pirated films sold in Indonesia were first distributed by sea from Singapore, with a transit on the island of Batam. After transportation by boat from Batam the films were distributed over land to Medan, Jakarta, Semarang, and Surabaya, and from there to the rest of Indonesia. By 1998, not just

12 'Belasan juta VCD illegal beredar di pasaran', Angkatan Bersenjata, 20-8-1997.

13 'VCD bajakan punya pasar tersendiri', Pelita, 27-7-1999.

14 'Kaset bajakan rambah pedesaan; Lebih banyak ketimbang di perkotaan', Sinar Pagi, 11-32000. 
pirated films, mostly in VCD format, were imported through these networks; the technologies to produce them were also disseminating themselves via the networks. In November 1998, it was estimated that there were approximately ten factories based in Jakarta, Semarang, and Surabaya producing pirated VCDs. ${ }^{15}$ The production of illegal VCD copies soon expanded, eventually transforming into an export commodity for markets in Malaysia, Singapore, India, and the Philippines. ${ }^{16}$ In the short space of a few years, film piracy was established as a substantial home industry business. In 2001, it was officially estimated that in Jakarta alone around one hundred copy machines were operating; however, in reality there were presumably many more. ${ }^{17}$

With the exception of pornographic films, pirated VCDs, both imported and domestically produced, were sold on the open market. The centre for pirated products in Indonesia was the Glodok area in Jakarta, but also in other cities and more rural towns pirated films were openly on offer in shops and stalls in shopping malls and on the streets. Similar to ordering a pizza, there were identical services by which pirated films could be ordered by phone. ${ }^{18}$ Even though the government lost an estimated amount of Rp 5 billion (US\$ 400,000) per year in taxes, media piracy was big business in Indonesia. ${ }^{19}$ Besides the vendors of the illegal film copies, those benefitting from this alternative site of film distribution and consumption were producers, importers, and distributors of pirated films, not to mention the police, government officials, and Soeharto business cronies. In short, many businesses and members of official organizations and the bureaucracy in Indonesia were involved in the production or distribution of pirated VCDs. Between 1997 and 2003, Indonesian media repeatedly mentioned that producers, distributors, and importers of established media organizations were also involved in the trade in illegal copies. It was said, and sometimes proven, that factories producing original VCDs simultaneously produced copies for the underground mar-

\footnotetext{
15 'Benda kaca mini berdaya rusak maksi' Media Indonesia, 8-11-1998.

16 Tim SP (2000) wrote an article about a syndicate of film piracy consisting of Glodok (North Jakarta), Singapore, and Batam mafia.

17 'Karena terdapat 100 mesin cetak VCD di Jakarta; Aksi pembajakan terus berlangsung', Pos Kota, 9-9-2001.

18 'Video bajakan beredar lewat "rental berjalan", Sinar Pagi, 15-12-1997.

19 This amount was estimated in May 1998 (Syah 1998). In 2003 the head of Karya Cipta Indonesia (Indonesian Intellectual Property), Rinto Harahap, stated that each year the state lost Rp 1.4 trillion (US\$ $116,666,666$; at the time 1 US \$ was approximately Rp 12,000) on pirated music cassettes and VCDs ('Kerugian negara capai Rp 1,4 trilliun/tahun', Pikiran Rakyat, 10-3-2003). By 2007 this amount had risen to Rp 2.5 trillion (US $\$ 263,157,894$; note that by then 1 US $\$$ was valued at around $\mathrm{Rp} 9,500$ ) (Hadysusanto 2008).
} 
ket. ${ }^{20}$ Certified film import and distribution networks, as well as cinema workers and staff, were rumoured to be part of the piratedfilm network, passing on master copies to illegal copiers. In addition to companies, others who profited from the production and distribution of pirated VCDs were the 'rotten elements' (oknum) in the police forces and ruling elites. It was common knowledge that small-scale producers, distributors, and sales people regularly paid policemen a fee so as to continue their business undisturbed. Vendors of pirated VCDs were especially prone to handing out payments to pre-empt police raids, or at least to be warned prior to any police actions. Allegedly, large business empires in the illegal film industry were backed either by Soeharto cronies, high-ranking army officers, or legislative officials. ${ }^{21}$

Despite the fact that these goods were sold openly, piracy in Indonesia was officially illegal. Between 1993 and 1997, several new intellectual property laws and sanctions against offenders were approved in parliament. In 1997 a law on intellectual property rights was passed. Offenders against this law could be sentenced to five years imprisonment or a fine of Rp 50 million (US\$4,000). In the same period, sporadic raids were mounted by police forces, mainly in the Glodok area in Jakarta. These raids were primarily pro-forma to show there was police action against piracy and as a reminder to vendors to continue to pay their 'safety fees' (uang keamanan). During these raids thousands of pirated films were confiscated, some of which were later publicly destroyed. Every few months, in a ceremony attended by members of the LSF, police, and government officials, confiscated pirated films and cuts of censored films were run over by trucks or incinerated. This sanctioned destruction was filmed and subsequently featured in news programmes on television; details were also published in newspapers. In reality the ceremony was just as much fiction as the films themselves. Only a day after piracy raids took place, if not the same evening, the same number and variety of films was again on offer and it was business as usual. ${ }^{22}$ Occasionally producers or distributors of pirated films would be arrested. These culprits were mainly middlemen, who were back in business shortly after the payment of their bail.

20 'Bos pembajak, orang yang kebal hukum', Warta Kota, 18-4-2002; 'Rumah pembajak VCD di Teluk Gong digerebek', Warta Kota, 18-9-2002; Nurhan and Theodore 1999b.

21 See for example 'Kisruh penerbitan stiker legalisasi LD \& VCD; Keluarga Cendana terlibat?', Majalah Film 332/298/XV, 6/19-3-1999; 'Keluarga Cendana terlibat peredaran VCD bajakan', Harian Terbit, 20-2-1999.

22 See, for example, 'Tanpa pembinaan, razia VCD sia-sia', Media Indonesia, 24-3-1998; 'VCD bajakan', Pikiran Rakyat, 17-5-2000; 'Polisi bakar sekitar satu juta VCD bajakan', Republika, 27-102001. 
Around 1998 the raids began to increase. By then, Indonesia had achieved the third position on the 'priority watch list' of the International Intellectual Property Alliance (IIPA), an industry lobby group from the US. The principal reason for the increase in police raids against film piracy were the conditions set for foreign aid and funding by the International Monetary Fund (IMF). To facilitate loans and foreign aid after the Asian monetary crisis in 1997, Indonesia had to agree to fifty stipulations drawn up by IMF (Van Dijk 2001:82, 104). One of these demanded that the Indonesian government seriously combat offenders against intellectual property rights. ${ }^{23}$ However, even though the number of raids increased, and concomitantly the number of films that were burned or run over by trucks at the broadcast public ceremonies, the piracy industry in Indonesia, as in other Asian countries, in no way diminished. In 2003 the Motion Picture Association (MPA), the international division of the Motion Picture Association of America (MPAA), launched an anti-piracy media campaign in eight countries in Asia. Besides Indonesia, the campaign covered South Korea, Chinese Taiwan, India, Malaysia, Singapore, the Philippines, and Thailand. MPA estimated that the US motion picture industry lost more than US\$ 3 billion annually in potential worldwide revenue as a result of piracy. In 2002 six million DVDs, or $87 \%$ of pirated DVDs the world over, were seized in Asia. Hence 2003 was declared the 'Anti-Piracy Action Year in Asia', with the tagline 'Nothing beats the real thing: say 'no' to piracy' (Santosa 2003).

Both the post-Soeharto film festivals and networks of, mainly pirated, VCDs provided alternative sites of film distribution and consumption. Particularly the pirated VCDs offered wide access to all kinds of uncensored, mainstream and non-mainstream, domestic and foreign film productions. Furthermore, the different film festivals screened various films that never reached Indonesian television or cinemas. The discourses linking local cultures to independent or 'side-stream' film and its distribution and exhibition networks cannot be applied to the alternative sites without some difficulty. The first hurdle is that the post-Soeharto film festivals and VCD networks circulated both domestic and transnational films. As such, they did not represent either domestic or transnational culture, but a combination of both. Moreover, at the new film festivals identifications and issues of representation did not spring from global, national, or local concerns or cultures. Instead, these were based on particular film genres and film formats and the domestic and transnational

23 It was not the first time the Indonesian government and entertainment industry were pressured to take action against piracy. For example, in 1987 the US had restricted trade in other Indonesian business sectors because of music piracy. 
discourses which were linked to these genres and formats. Hence $\mathrm{Q}$ stood for discourses on gay and lesbian films and homosexuality, both in Indonesia and abroad; FFD represented discourses on the specificity of documentary film in Indonesia, as well as worldwide contemporary discourses on the genre; and PSI and Hello;fest were connected to discourses on the development, position, and implications of the video format in Indonesia and at other comparable festivals in the world. Jiffest, which screened all genres and formats, in this sense was all-inclusive, but through its annual changing festival theme each year it related to a specific discourse. ${ }^{24}$

The second problem in defining post-Soeharto film festivals and VCD networks is that it is difficult to determine which distribution and consumption channels were mainstream, side-stream, or underground. The understanding of these notions is multifaceted, as it consists of networks of distribution and consumption of original VCDs and of pirated films. Which networks represented mainstream distribution channels, those of legal films because they were legal? Or conversely, the networks of pirated VCDs? Even though piracy was an illegal activity in Indonesia, pirated films were openly on sale everywhere. Strictly speaking, from the point of view of availability and market shares, pirated films with a share of $90 \%$ against a mere $10 \%$ of legal films were more mainstream than their original counterpart. As such, the network and sales of original films could be perceived as a 'side-stream' channel of film distribution and consumption. Furthermore, because of the wide-ranging set-up of home industries producing pirated films, the vast transnational networks distributing them, the numerous vendors who sold these films all over Indonesia, and the substantial involvement of 'infiltrators' in official film production and distribution companies and organizations, police forces, and the judicial system, pirated VCDs could hardly be said to constitute an underground economy; rather, they formed a parallel economy.

Looking at film festivals the notion of mainstream versus sidestream sites of distribution and consumption is less complex in the sense that all festivals could be perceived as side-stream distribution channels because they were not initiated, supported, or run by the Indonesian state or film industry. However, on the basis of their visibility, or the amount of publicity they generated, some could be perceived as more 'side-stream' or underground than others. Instead of a division into mainstream, side-stream, or underground

24 For example, the main theme of Jiffest in 2000 was 'Issues on contemporary Islamic culture', while in 2001 it sounded 'Indonesian identity seen through film'. In 2002, the focus was 'Multiculturalism; Celebrating diversity', while Jiffest 2003 was about 'Understanding change'. 
events, in this context it might be better to speak of events that were on or off the map. Or, to use a phrase coined by co-founder of Konfiden and film-maker and distributor Lulu Ratna, 'festivals below the radar'. This term refers to low-profile festivals, as opposed to festivals that were easily detectible (Ratna 2005). In this context, Jiffest was a very visible, high-profile event that generated a wealth of national publicity. In comparison, $Q$, which remained low profile, could be perceived as a festival that was more distinctly nonestablishment. PSI, which was not of any interest to the national media, was an off-the-map, below-the-radar, underground event.

The discourses about local forms of resistance to processes of transnational cinematic neo-imperialism cannot simply be applied to the alternative sites of post-Soeharto film festivals and VCDs. However, these alternative channels of film distribution and exhibition do represent tactics which resisted or evaded hegemonic structures of film circulation. In this context, the festivals can be connected to the organization of film festivals worldwide as forums for alternative, off-beat film productions. Undoubtedly, on another level, the circulation of (particularly pirated) VCDs does represent tactics which resisted or evaded hegemonic structures of film distribution and exhibition. The circulation of pirated VCDs can be seen as a form of resistance, which Shohat and Stam (1994) call 'media jujitsu'.

As mentioned earlier, the political disposition of economic domination of First over Third Worlds and its concomitant global distribution of power was an important aspect in Third Cinema theories. ${ }^{25}$ Assessments of Third Cinema point to various film formulas which challenged First World domination of culture and aesthetics. These included films and videos which eschewed formal conventions of dramatic realism and chose modes and strategies of alternative aesthetics rooted in non-realist, often non-Western or para-Western, cultural traditions. Among the range of modes and strategies were the carnivalesque, the anthropophagic, the magicrealist, the reflexive modernist, and the resistant post-modernist.

25 Shohat and Stam remarked that the global cultural situation was not as one-sided as presented in media-imperialism theories of the 1970 s, but was in fact considerably more interactive. In their argument they mention that it was not a case of an active First World forcing its products onto a passive Third World. Global mass culture did not replace local cultures but co-existed with them, or was itself marked by a 'local' accent. For a similar argument, see Grewal and Kaplan's introduction (1994) to Scattered hegemonies; Postmodernity and transnational feminist practice. Furthermore, Shohat and Stam argued, a growing number of Third-World countries (Mexico, Brazil, India, and Egypt) dominated their own markets and even became cultural exporters. According to Shohat and Stam (1994:31) a distinction should be made between the ownership and control of the media, which is an issue of political economy, and the specifically cultural issue of the implications of this domination for the people on the receiving end. 
These featured other historical rhythms, other narrative structures, and other views of collective life. ${ }^{26}$

Shohat and Stam indicate that many of these modes and strategies appropriated existing discourses to their own ends. In this, Shohat and Stam argue, the power of dominant First World discourses was assumed only to deploy its force through a kind of artistic jujitsu against domination. So did the Brazilian anthropophagic movement, which 'called for an art that would devour European techniques the better to struggle against European domination', most alternative aesthetics revalourized what was seen as negative, and turned tactical weakness into strategic strength (Shohat and Stam 1994:328). As mentioned above, Shohat and Stam call the appropriation of elements of dominant culture to redeploy them in the interests of oppositional praxis 'media jujitsu'.

The concept of media jujitsu can be extended to the distribution and consumption practices of pirated VCDs. Similar to strategies that appropriated dominant discourses and aesthetics only to transform these into a force against domination, the alternative site of distribution and consumption of pirated VCDs is one which incorporated First World cultural domination and supported the dissemination of its foreign hegemony, but simultaneously undermined it. Paradoxically, the networks of pirated VCDs represented the most accessible channels to hegemonic First World culture, while they simultaneously destabilized the disposition of First World economic domination. Pirated VCDs can be perceived as a form of resistance to both national control and structures of film: they evade state censorship and sidestep the lack of choice in films available via mainstream channels. These VCDs also resist the global economic domination and distribution of power of the West by undermining legal sales and copyrights. The format and its cursive practices of mediation dispersed hegemonies of leading global and national audiovisual media networks. ${ }^{27}$

\section{CONCLUSION}

Discourses on post-Soeharto film mediation practices depended on reconstituted frames of reference. New media technologies and

26 Shohat and Stam 1994:292. For a comprehensive description of these modes and strategies and their implications, see Shohat and Stam 1994:292-337.

27 For concepts on contemporary 'dispersed' and 'scattered' hegemonies in global-local cultural relations, see Appadurai 1990; Grewal and Kaplan 1994, notably the Introduction. 
changes on the political scene led to new 'independent' film practices, cultures, and imaginations of identities, but old practices, cultures, and identities were not entirely disposed of. Ironically, the democratization process of audio-visual media launched by the advance in new technologies caused another divide in film formats, audiences, and communities. This time, instead of $16 \mathrm{~mm}$ film, the new digital video format was in conflict with Cinema 21's $35 \mathrm{~mm}$ format.

Since the overwhelming interest in the affair surrounding Beth, Cinema 21 stopped screening films in digital format. Films must now be transferred to $35 \mathrm{~mm}$ before they will be shown in its cinemas. The new policy strengthened the impression that the network supported long-standing power structures, as it limited the number of domestic films to reach top-end cinemas. Only film-makers or producers who could pay for the production or 'blow-up' of their film in the $35 \mathrm{~mm}$ format could have their films screened in Cinema 21. Consequently, film-makers with proficient business knowhow and 'connections', or sufficient financial backing, had an advantage. Nevertheless, the film format alone was not the reason that few domestic films reached the Indonesian top-end theatres; the duration, content, and style of the films also had to comply with the criteria set by Cinema 21. Those who could not live up to these conditions had the old alternative of 'going international' and screening films at foreign film festivals. The new alternative was to 'go independent' and distribute and screen films via alternative networks, or to distribute them directly in VCD format. ${ }^{28}$

The choice for old, new, established, or alternative channels of film distribution and exhibition was based not merely on practical considerations, but also on who, and what, these channels were perceived to represent in post-Soeharto Indonesia. In debates about the failure of Beth to reach Cinema 21, the mainstream movie theatre network epitomized entrenched structures of domination by Jakarta related to national (New Order) and transnational (Hollywood) identities. These structures were set against alternative independent networks, which connoted local resistance. The juxtaposition of local against national and transnational identities is exemplified in the contrast between Jelangkung and Beth. Jelangkung stands for perceptions of power, commerce, elites, and a combination of transnational and national culture and identities. These features are pitched against Beth, which represents the discourses on

28 For details about an increase in distribution of domestic films in the VCD format in the last years of New Order rule, see JB Kristanto 2005:xiii-xiv. 
a lack of power, idealism, and common people, which supposedly corresponds with local culture and identities.

The distribution and consumption of film in VCD format undermined the aforementioned connotations of mainstream, 'sidestream', and underground film mediation practices and identities. Virtually everyone - elites and common people, both in Jakarta and in rural areas - watched pirated films. The specific conditions and socio-political implications of pirated VCDs challenged the hegemony and rules of dominant national and transnational media networks. The cursive practices of film mediation evaded censorship and circumvented the lack of choice in films which were available through national mainstream channels. They moreover resisted the West's global economic domination and power by subverting legal sales and copyrights. However, the VCD circuit as an alternative site for film distribution and consumption did not weaken the position and influence of Indonesian elites. As before they had corrupted the networks of layar tancep now, elites appropriated the circulation of VCDs to profit from piracy through the production, distribution, and sales of illegal films, or by having their share in 'security' levies. Beth and film independen, Jelangkung and Cinema 21, as well as post-Soeharto film festivals and (pirated) VCDs illustrate how alternative film cultures and the powers that be opposed and also used each other in the post-Soeharto mediascape. 